\title{
ANALISIS KECAKAPAN HIDUP SISWA PADA PEMBELAJARAN EKONOMI KREATIF MELALUI PEMBELAJARAN BERBASIS PROYEK DI SMA NEGERI 15 PALEMBANG
}

\author{
Rafika Rahmadani ${ }^{1}$, Riswan Jaenudin ${ }^{2}$ dan Ikbal Barlian ${ }^{3}$ \\ ${ }^{1}$ Alumni Pendidikan Ekonomi FKIP Universitas Sriwijaya \\ 1,2Dosen Pendidikan Ekonomi FKIP Universitas Sriwijaya \\ Email: rafikarahmadani@gmail.com
}

\begin{abstract}
Abstrak
Penelitian ini berjudul Analisis Kecakapan Hidup Siswa Pada Pembelajaran Ekonomi Kreatif Melalui Pembelajaran Berbasis Proyek di SMA Negeri 15 Palembang. Rumusan masalah pada penelitian ini adalah bagaimana nilai-nilai kecakapan spesifik siswa pada pembelajaran ekonomi kreatif di SMA Negeri 15 Palembang dan bagaimana pembelajaran ekonomi kreatif melalui pembelajaran berbasis proyek dapat memperlihatan nilainilai pada kecakapan spesifik siswa. Variabel penelitian ini adalah kecakapan hidup siswa yang dibatasi pada kecakapan spesifik dan difokuskan pada nilai-nilainya. Subjek penelitian ini adalah SMA Negeri 15 Palembang dengan siswa kelas X.IPS 2 dan satu guru mata pelajaran ekonomi kreatif. Data observasi digunakan untuk mengetahui nilai-nilai kecakapan spesifik siswa, angket digunakan untuk mengetahui tanggapan siswa terhadap pembelajaran ekonomi kreatif dan wawancara digunakan untuk mengetahui konsep pembelajaran ekonomi kreatif melalui pembelajaran berbasis proyek. Hasil penelitian ini menunjukkan bahwa nilai-nilai kecakapan spesifik siswa yang terdiri dari kecakapan akademik dan kecakapan vokasional terlihat cukup baik. Hasil untuk nilai kecakapan akademik adalah 68,7\% masuk dalam kategori cukup baik dan nilai kecakapan vokasional adalah 69.7\% dan dapat dikatakan cukup baik. Hal tersebut menunjukkan bahwa di dalam diri siswa memiliki nilai-nilai kecakapan hidup yang baik sehingga nilai-nilai tersebut dapat dijadikan sebagai proses pembentukan keterampilan diri siswa.
\end{abstract}

Kata kunci: kecakapan hidup, kecakapan akademik dan vokasional, ekonomi kreatif, pembelajaran berbasis proyek.

\section{PENDAHULUAN}

Dalam dunia pendidikan, ekonomi kreatif atau yang disebut juga dengan kewirausahaan merupakan salah satu mata pelajaran muatan lokal yang diterapkan pada jenjang Sekolah Menengah Atas (SMA) dan merupakan mata pelajaran wajib di Sekaolah Menengah Kejuruan (SMK). Terkait hal tersebut, pentingnya pembelajaran ekonomi kreatif ini diberikan kepada siswa, diharapkan akan mampu menciptakan insan yang kreatif dan mampu untuk menciptakan barang dan jasa yang baru atau menjadi wirausahawan yang mandiri dan mampu untuk menciptakan lapangan pekerjaan baru. Oleh karena itu, pemerintah menyadari bahwa konsep ekonomi kreatif yang diterapkan sejak pendidikan dasar akan mampu menciptakan insan kreatif dan menghasilkan wirausahawan tangguh yang mempunyai gagasan cemerlang dan baru.

Terkait dengan hal tersebut dengan adanya muatan lokal ekonomi kreatif maka dapat dinilai sebagai nilai kecakapan hidup (life skill) yang mengorientasikan siswa untuk memiliki kemampuan agar dapat hidup mandiri dan survive di lingkungannya. Salah satu strategi pembelajaran yang dapat membantu siswa agar memiliki kreativitas berfikir, pemecahan masalah, dan interaksi serta membantu dalam penyeldikan yang mengarah pada penyelesaian masalah-masalah nyata adalah project based learning atau pembelajaran berbasis proyek (Turgut, 2008:61).

Dalam penelitian terdahulu yang dilakukan oleh Imam Mawardi tentang "Pendidikan Life Skills Berbasis Budaya Nilai-Nilai Islami dalam Pembelajaran" pada Universitas Negeri Magelang mengatakan bahwa dengan nilai-nilai berbasis islam seperti berakhlak mulia, beramal kebaikan, menguasai ilmu, kehaliaan, amanah dan tanggung jawab berfungsi sebagai pembentuk kepribadian peserta didik sehingga peserta didik mempunyai sikap dari tingkah laku yang baik (etika, aklak dan 
moral). Disamping itu dapat pula menghasilkan pengembangan karya, untuk menjadi manusia terampil dan cakap teknologi yang menghasilkan kegunaan. (Mawardi, 2012:227)

Nilai-nilai yang terkandung dalam life skill seperti dikemukakan sebelumnya, merupakan nilai yang hendak dicapai yang dapat didekati dengan menggunakan pendekatan strategi pembelajaran. Integrasi strategi pembelajaran berbasis proyek dalam upaya menumbuhkan dan memberikan penguatan nilai-nilai kecakapan hidup siswa menjadi kajian utama dalam penelitian ini.

\section{METODE/EKSPERIMEN}

Penelitian ini dilaksanakan di SMA Negeri 15 Palembang, dengan waktu pelaksanaan semester genap tahun pelajaran 2014/2015. Pelaksanaan penelitian ini pada bulan April-Mei 2015. Populasi dalam penelitian ini adalah siswa kelas $X$ (sepuluh) SMA Negeri 15 Palembang yang terdiri dari sembilan kelas. Sampel dalam penelitian ini menggunakan Purposive Sampling, yakni berdasarkan pertimbangan. Menurut Sitorus, (1985:80) "Purposive Sampling adalah sampel yang diambil harus memiliki sifat tertentu yang sesuai dengan maksud penelitian dan sifat-sifat sampel itu dapat mewakili sifat-sifat populasinya. Sampel dalam penelitian ini adalah kelas X.IPS 2 yang terdiri dari 39 siswa. Variabel dalam penelitian ini adalah kecakapan hidup spesifik, yang terdiri dari kecakapan akademik dan vokasional

Pada penelitian ini indikator yang diuraikan untuk melihat aspek kecakapan akademik pada peserta didik meliputi, 1) menjelaksan konsep prakarya yang dibuat dilihat dari bahan-bahan yang digunakan, 2) membuat keterkaitan antar bahan dan alat yang akan digunakan, 3) membuat gambaran mengenai prakarya yang akan dihasilkan dilihat dari langkah kerja dan bentuknya, 4) bekerja sesuai dengan langkah-langkah yang telah disiapkan dan 5) menghasilkan produk berupa barang yang memiliki unsur estetika.

Pada penelitian ini indikator yang diuraikan untuk melihat aspek kecakapan vokasional pada peserta didik meliputi, 1) melakukan gerak dasar dalam penggunaan alat, baik alat mesin otomatis maupun manual, 2) berperilaku taat asas dan tepat waktu dalam menyelesaikan proyek, 3) berprilaku produktif terhadap apa yang telah dihasilkan, 4) berinovasi sesuai dengan potensi diri dan kesesuaian produk dan 5) menghasilkan produk yang mempunyai unsur efisien dan estetika.

\section{Teknik Pengumpulan Data}

Teknik pengumpulan data pada penelitian ini adalah menggunakan observasi, angket dan dokumentasi.

Teknik Analisis Data

a. Angket instrumen yang digunakan dalam penelitian mengenai pembelajaran ekonomi kreatif ini berupa angket yang menggunakan pendekatan skala Likert.

b. Observasi dan wawancara

c. Lembar observasi dan wawancara digunakan untuk memperoleh data mengenai nilai kecakapan hidup dan pembelajaran ekonomi kreatif melalui pembelajaran berbasis proyek. Skala penilaian pada teknik pengumpulan data observasi dan wawancara adalah 0 tidak ada deskriptor yang tampak dan 1 ada deskriptor yang tampak.

Tabel 1. Kriteria Nilai Kecakapan Hidup dan Pembelajaran Ekonomi Kreatif melalui Pembelajaran

\begin{tabular}{cc}
\multicolumn{2}{c}{ Berbasis Proyek } \\
\hline Persentase (\%) & Kategori \\
\hline $85 \%-100 \%$ & Sangat Baik \\
$75 \%-84 \%$ & Baik \\
$60 \%-74 \%$ & Cukup Baik \\
$40 \% 59 \%$ & Kurang Baik \\
$0 \%-39 \%$ & Gagal \\
\hline
\end{tabular}

Sumber : Jurnal Life skill, UNESA: 11 


\section{HASIL DAN PEMBAHASAN}

Deskripsi lokasi penelitian ini dilakukan di SMA Negeri 15 Palembang yang terletak di Jl. KS. Tubun No 10 Palembang kecamatan llir Timur I sumatera selatan dengan pimpinan Bapak Drs. Syamsul Bachri,M.Si sebagai kepala sekolah. Dengan fasilitas yang cukup memadai dan tenaga pendidik yang cukup berkualitas nsehingga pelaksanaan pembelajaran di sekolah dapat dikatakan cukup baik. Deskripsi data penelitian ini diuraikan menjadi tiga sub bagian, antara lain adalah deskripsi data hasil observasi, angket dan wawancara.

\section{DESKRIPSI DAN HASIL PENELITIAN}

\section{Deskripsi Data Hasil Observasi}

Data hasil observasi ditujukkan kepada siswa dan dilakukan peneliti sebanyak 2 kali yakni pada tanggal 19 Mei 2015 pada jam ke 1 sampai jam ke 3 dan pada tanggal 23 Mei 2015 di kelas X.IPS 2. Observasi dilakukan pada saat pembelajaran ekonomi kreatif berlangsung dengan materi pemanfaatan kain perca. Penugasan proyek ini menugaskan bahwa kain perca dapat dimanfaatkan sebagai hasil karya yang memiliki nilai guna seperti, kotak pensil, sarung tangan dan taplak meja. Data yang diperlukan pada hasil observasi ini adalah data mengenai nilai- nilai kecakapan spesifik siswa, yakni kecakapan akademik dan vokasional dalam bentuk jawaban pilihan dari hasil pengamatan yang dilakukan peneliti. Adapun nilai-nilainya antara lain adalah nilai ketelitian, kedisiplinan, kerja sama, tepat waktu, inovatif, estetika, memiliki nilai jual, produksi berkelanjutan dan nilai daya saing. Nilai-nilai kecakapan hidup tersebut di observasi pada setiap aspek kecakapan akademik dan kecakapan vokasional siswa. Di dalam kecakapan akademik terdapat beberapa komponen yakni mengidentifikasi variabel dan menghubungkan antara satu variabel dengan variabel lainnya, merumuskan hipotesis, merancang dan menghasilkan penelitian, dan untuk kecakapan vokasional yakni melakukan gerak dasar dan menggunakan alat sederhana sampai dengan menghasilkan barang atau jasa.

\section{Deskripsi Data Hasil Angket}

Data yang diperlukan pada angket adalah data mengenai pembelajaran ekonomi kreatif dalam bentuk jawaban pilihan dari siswa. Peneliti melihat pembelajaran ekonomi kreatif sebagai pembelajaran yang memiliki nilai-nilai kecakapan hidup. Pembelajaran ekonomi kreatif di SMA Negeri 15 Palembang adalah pembelajaran yang diberikan karena kebutuhan sekolah dan diberikan sebagai mata pelajaran muatan lokal. Adapun indikator pada lembar angket adalah mengenai persepsi siswa tentang konsep pembelajaran ekonomi kreatif, yakni pemahaman mata pelajaran ekonomi kreatif, ketertarikan pembelajaran ekonomi kreatif, kesiapan dalam mengikuti proses pembelajaran ekonomi kreatif, fungsi pembelajaran ekonomi kreatif, dan produk yang dihasilkan pada pembelajaran ekonomi kreatif.

3. Deskripsi Data Hasil Wawancara

Data yang diperlukan pada wanwancara adalah uraian jawaban mengenai pembelajaran ekonomi kreatif melalui pembelajaran berbasis proyek. Dimana pembelajaran tersebut dapat memperlihatkan nilai-nilai kecakapan hidup siswa. dalam hal ini diketahui bahwa pembelajaran yang diintegrasikan dengan nilai-nilai kecakapan hidup dapat muncul dengan baik dan dapat pula diketahui letak kelemahan dan kelebihan pada proses pembelajaran. Pada wawancara ini ditujukan kepada 1 guru mata pelajaran ekonomi dengan inisial SR.

\section{HASIL ANALISIS}

\section{Hasil Analisis Data Observasi}

Setelah dilakukan observasi oleh peneliti selama proses pembelajaran ekonomi kreatif dengan materi pemanfaatan kain perca, maka didapatlah data tentang nilai kecakapan spesifik siswa, yakni kecakapan akademik dan vokasional. Peneliti mengelompokkan hasil data observasi berdasarkan kelompok, dimana terdiri dari 4 kelompok dan masing-masing kelompok terdapat 10 siswa. Dari hasil olah data observasi untuk nilai kecakapan akademik dan vokassional siswa di kelas X.IPS 2 di SMA Negeri 15 Palembang dapat di jelaskan dalam tabel berikut ini: 
Rafika Rahmadani ${ }^{1}$, Riswan Jaenudin ${ }^{2}$ dan Ikbal Barlian ${ }^{3}$

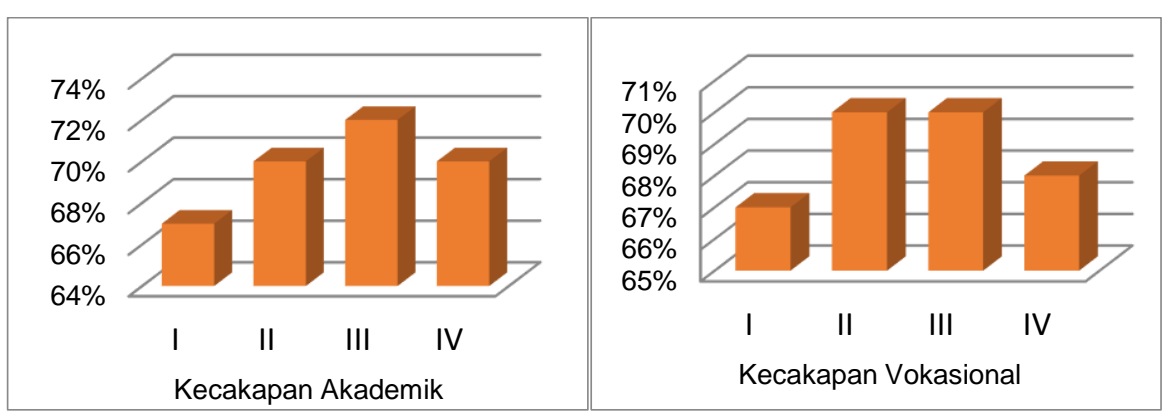

Gambar 1. Hasil Observasi Nilai-nilai Kecakapan Akademik dan Kecakapan Vokasional Sumber : Data Primer Penelitian

Berdasarkan tabel rekapitulasi dan diagram diatas, untuk nilai kecakapan akademik siswa pada mata pelajaran ekonomi kreatif dapat dilihat bahwa rata-rata dari keseluruhan siswa kelas X.IPS 2 masuk kedalam kategori cukup baik atau setara dengan 69,7\%. Sedangkan untuk nilai kecakapan vokasional masuk kedalam kategori cukup baik atau setara dengan 68,7\%. Jadi dapat disimpulkan bahwa nilai-nilai kecakapan akademik dan vokasional siswa di kelas X.IPS 2 dapat dikatakan cukup baik.

\section{Hasil Analisis Data Angkat}

Angket merupakan teknik yang digunakan peneliti sebagai peranan dari pembelajaran ekonomi kreatif bagi siswa setelah diadakan observasi. Angket ini diberikan kepada siswa dengan indikator yang berbeda dengan oservasi dan wawancara.

Hasil angket siswa terhadap pembelajaran ekonomi kreatif menunjukkan ada 18 siswa yang masuk kedalam kategori sangat baik. Dalam rentang siswa tersebut diantaranya ada satu (1) siswa dengan total persentase $94,6 \%$, dua (2) siswa dengan $92,8 \%$, satu (1) siswa dengan $91 \%$, tiga (3) siswa dengan $89,2 \%$, tiga (3) siswa dengan $87,5 \%$ dan delapan (8) siswa dengan total persentase $85,7 \%$. Selanjutnya, angket menunjukan bahwa ada 19 siswa yang masuk kedalam kategori baik, diantaranya adalah tiga (3) siswa dengantotal persentase $75 \%$, dua (2) siswa dengan 76,7\%, dua (2) siswa dengan $78,5 \%$, empat (4) siswa dengan $80,3 \%$, tiga (3) siswa dengan $82,1 \%$ dan lima (5) siswa dengan total $83,9 \%$. Untuk siswa yang masuk dalam kategori cukup baik sebanyak tiga (3) siswa dengan total persentase $73,2 \%$. Jadi berdasarkan hasil rata-rata persentase dari empat puluh siswa dengan empat belas item pernyataan angket tersebut adalah 83,4\% dan dikategorikan baik.

\section{Hasil Analisis Wawancara}

Berdasarkan hasil wawancara dapat dijelaskan bahwa indikator 1 guru SR menjelaskan bahwa pelaksanaan pembelajaran ekonomi kreatif menggunakan pembelajaran berbasis proyek, oleh karena itu diberi skor 1 , indikator 2 tidak menunjukkan keefektifan maka diberi skor 0 , indikator 3 mejelaskan adnaya ketertarikan siswa, maka diberi skor 1, indikator 4 menunjukkan peran pembelajaran ekonomi kreatif terhadap siswa, maka diberi skor 1 dan indikator 5 menunjukkan adanya nilai-nilai dari kecakapan spesifik yang muncul dari siswa, maka diberi skor 1. Berdasarkan perhitungan hasil wawancara yang dilakukan oleh peneliti kepada guru SR maka dapat disimpulkan bahwa pembelajaran ekonomi kreatif melalui pembelajaran berbasis proyek dikategorikan baik dengan total persentase $80 \%$.

\section{PEMBAHASAN}

Dalam kecakapan spesifik, peserta didik diharapkan mampu menguasai kecakapan secara akademik dan vokasional. Kecakapan akademik seringkali juga disebut kecakapan intelektual atau kemampuan berpikir ilmiah, hal itu didasarkan pada pemikiran bahwa bidang pekerjaan yang ditangani memang lebih memerlukan kecakapan berpikir ilmiah (Asmani, 2009:53). Komponen yang perlu dikuasai pesera didik dalam kecakapan akademik antara lain adalah mengidentifikasi variabel dan menghubungkan antara satu variabel dengan variabel lainnya, merumuskan hipotesis, merancang dan menghasilkan penelitian, dimana komponen tersebut dinyatakan oleh (Depdiknas,2008:11). Untuk bidang yang perlu dikuasai peserta didik dalam kecakapan vokasional terbagi menjadi dua yaitu, 
vokasional dasar dan vokasional khusus yang berkaitan dengan keterampilan siswa. Adapaun komponen yang mencakup pada kecakapan vokasional dasar adalah melakukan gerak dasar dan menggunakan alat sederhana, sedangkan komponen yang mencakup kecakapan vokasional khusus adalah menghasilkan barang atau jasa.

Dari kedua kecakapan spesifik tersebut, peneliti melihat nilai-nilai yang muncul pada kecakapan akademik dan vokasional. Dimana nilai-nilai yang muncul nantinya akan diketahui melalui pembelajaran ekonomi kreatif melalui pembelajaran berbasis proyek. Nilai yang muncul antara lain adalah nilai ketelitian, disiplin, kerjasama, tepat waktu, inovatif, estetika, nilai jual, produksi berkelanjutan dan memiliki daya saing. Hal tersebut didukung oleh temuan dari penelitian (Tarigan, 2011) yang mengatakan bahwa nilai-nilai kecakapan hidup (life skill) antara lain adalah bertanggung jawab, bekerja keras, jujur dan lain-lain. Nilai-nilai tersebut diharapkan mampu memberikan kontribusi kepada nilai-nilai karakter bangsa indonesia. Penelitian ini dibatasi oleh aspek nilai-nilai kecakapan hidup dan mata pelajaran yang diteliti adalah mata pelajaran ekonomi kreatif. Hal ini berarti bahwa peneliti tidak melihat aspek secara psikologi siswa dan tidak juga melihat mata pelajaran bidang lainnya karena hal tersebut bukan cakupan dari kebutuhan peneliti.

Berdasarkan hasil observasi, angket dan wawancara oleh peneliti terkait dengan analisis nilai dari kecakapan spesifik pada pembelajaran ekonomi kreatif melalui pembelajaran berbasis proyek di SMA Negeri 15 Palembang dapat disimpulkan bahwa dari masing-masing siswa berdasarkan indikatorindikator yang diamati memiliki hasil yang berbeda-beda.

Data penelitian ini dikumpulkan melalui observasi yang ditujukan kepada siswa kelas X.IPS 2 dengan jumlah 40 siswa. Peneliti melakukan observasi kepada siswa secara individu tetapi dengan strategi berkelompok. Observasi ini dilakukan untuk melihat nilai yang muncul dari kecakapan akademik dan vokasional siswa pada pembelajaran ekonomi kreatif. Berdasarkan hasil penelitian yang telah dilakukan, diketahui bahwa sebagian besar siswa kelas X. IPS 2 SMA Negeri 15 Palembang memiliki nilai kecakapan akademik dan vokasional yang cukup baik. Hasil observasi pada penelitian ini mengatakan bahwa nilai-nilai yang muncul dari kecakapan akademik siswa dapat dilihat dari hasil penelitian pada tabel 25 yang mengindikasikan bahwa sebagian besar nilai nilai dari kecakapan akademik siswa masuk dalam kategori cukup baik atau setara dengan $69,7 \%$. Sedangkan hasil observasi niai-nilai pada kecakapan vokasional siswa terkategorikan cukup baik atau setara dengan $68,7 \%$.

Untuk hasil angket pada penelitian ini merujuk pada tanggapan siswa mengenai pembelajaran ekonomi kreatif. Indikator pada angket ini adalah mengenai pemahaman mata pelajaran ekonomi kreatif, ketertarikan belajar ekonomi kreatif, kesiapan dalam proses pembelajaran ekonomi kreatif, fungsi belajar ekonomi kreatif dan hasil karya pada pembelajaran ekonomi kreatif. Aspek-aspek tersebut dianalisis oleh peneliti dengan tujuan untuk melihat seberapa baikkah tanggapan siswa mengenai pembelajaran ekonomi kreatif yang dapat memunculkan nilai-nilai kecakapan hidup. Berdasarkan hasil rekapitulasi angket terlihat bahwa tanggapan siswa kelas X.IPS 2 terhadap pembelajaran ekonomi kreatif dapat dikategorikan baik atau setara dengan $83,4 \%$.

Selanjutnya hasil dari wawancara ditujukan kepada guru SR untuk mengetahui bahwa pembelajaran ekonomi kreatif melalui pembelajaran berbasis proyek ini dapat memperlihatkan nilainilai dari kecakapan spesifik siswa. indikator pada wawancara ini antara lain adalah pelaksaaan pembelajaran ekonomi kreatif melalui pembelajaran berbasis proyek, keefektifan pembelajaran berbasis proyek pada mata pelajaran ekonomi kreatif, ketertarikan siswa dalam pembelajaran ekonomi kreatif, peran pembelajaran ekonomi kreatif dalam meningkatkan kecakapan akademik dan vokasional dan Nilai-nilai kecakapan spesifik yang ada pada pembelajaran ekonomi kreatif. Aspek-aspek tersebut diharapkan muncul pada teknik wawancara guru

Hasil penelitian wawancara mengatakan bahwa ada 1 deskriptor yang tidak tampak yakni pada aspek keefektifan karena penggunaan pembelajaran berbasis proyek yang terkadang kurang efektif bagi siswa. Untuk deskriptor lain terlihat tampak pada wawancara teradap guru SR. Dari hasil wawancara indikator yang diberikan pada gur SR masuk dalam kategori baik atau setara dengan $80 \%$. 
Berdasarkan hasil penelitian dan pembahasan diatas, dapat disimpulkan bahwa nilai-nilai kecakapan spesifik siswa yang terdiri dari kecakapan akademik dan vokasional pada pembelajaran ekonomi kreatif di SMA Negeri 15 Palembang adalah cukup baik. Dalam pembelajaran ekonomi kreatif melalui pembelajaran berbasis proyek diperoleh kesimpulan bahwa pembelajaran tersebut dapat memperlihatkan nilai-nilai kecakapan pada kecakapakan akademik dan kecakapan vokasional dan dapat dikategorikan baik.

\section{SIMPULAN}

\section{PENUTUP}

Berdasarkan hasil dari analisis data observasi, angket, wawancara dan pembahasan terhadap nilai-nilai kecakapan hidup khususnya pada kecakapan spesifik dalam pembelajaran ekonomi kreatif pada pembelajaran berbasis proyek, maka dapat disimpulkan bahwa dalam nilai-nilai pada kecakapan akademik dan kecakapan vokaasional siswa kelas X IPS 2 di SMA Negeri 15 Palembang dapat dikatakan cukup baik. Nilai-nilai kecakapan hidup yang ada pada siswa adalah nilai-nilai yang dapat membentuk karakter siswa sebagai bekal keterampilan mereka. Nilai-nilai yang berhubungan dengan keterampilan diri, mampu didapatkan dari pembelajaran ekonomi kreatif, dimana pembelajaran ekonomi kreatif ini merupakan salah satu inovasi dari pembelajaran ekonomi yang dapat melahirkan siswa untuk terampil dan menghasilkan sebuah karya.

Nilai-nilai kecakapan akademik dan vokasional yang dapat diperlihatkan pada pembelajaran ekonomi kreatif adalah teliti, disiplin, kerjasama, tepat waktu, inovatif, memiliki nilai jual, produksi berkelanjutan dan daya saing. Nilai-nilai tersebut diharapkan muncul dengan baik pada setiap kecakapan akademik dan vokasional siswa, namun pada hasil penelitian ini nilai-nilai yang muncul masuk dalam kategori cukup baik, yang artinya ada beberapa indikator yang tidak tercapai secara maksimal.

\section{SARAN}

Untuk menganalisis nilai-nilai dari kecakapan hidup siswa dalam pembelajaran di sekolah disarankan kepada :

1. Guru-guru lebih menggali nilai-nilai kecakapan hidup yang ada dalam diri siswa. Selain itu guru juga dapat memasukkan aspek psikologi siswa terhadap suatu pembelajaran

2. Sekolah agar lebih menawarkan nilai-nilai kecakapan hidup bukan hanya pada pembelajaran ekonomi kreatif saja, tetapi dapat diterapkan pada pembelajaran lainnya. Selain itu sekolah dapat mengimplementasikan nilai-nilai kecakapan hidup ini sebagai proses pembentukan keterampilan diri siswa.

3. Peneliti selanjutnya diharapkan untuk mempersiapkan bekal pemahaman teori lebih dalam mengenai nilai-nilai dari kecakapan hidup siswa.

\section{DAFTAR PUSTAKA}

Anwar, 2006. Pendidikan Kecakapan Hidup (Life Skills Education) Konsep dan Aplikasi. Bandung: Alfabeta.

Depdiknas. 2003. Undang-Undang Republik Indonesia Nomor 20 Tahun 2003 Tentang Sistem Pendidikan Nasiona, Jakarta: Depdiknas.

E, Mulyasa. 2004. Kurikulum Berbasis Kompetensi, Konsep, Karakteristik dan Implementasi. Bandung: PT Remaja Rosdakarya.

George Lucas Educational Foundation, 2005. Intructional Module Project Based Learning.(Diaksesmelaluihttp://www.edutopia.org/modules/PBL/whatpbl.php 10-08-2014) 
78 | Titian IImu: Jurnal IImiah Multi Sciences Vol. IX No. 2, 2017

Jamal Ma’mur Asmani. 2009. Sekolah life skill, Lulus Siap Kerja. Yogyakarta: Diva Press.

Kattsoff, Louis O. 1992. Element of Philosophy, Alih Bahasa Soejono Soemargono. Yogyakarta: Tiara Wacana

Mawardi, Imam. 2012. Pendidikan Life Skills Berbasis Budaya Nilai-nilai Islami dalam Pembelajaran.(Dimuat dalam Jurnal Pendidikan Islam Vol. 6. No.2. Oktober 2012)

Michael, M. Grant, 2002. Getting A Grip on Project Based-Learning: Theory, Cases and Recomendations. North Carolina: Meredian A Middle School Computer Technologies Journal (vol 5 2002, hal 1-3).

Pardjono. 2003. Kecakapan Hidup (Life skill) dan Urgensinya Bagi Sekolah Menengah Kejuruan (Dimuat dalam Jurnal Pendidikan Teknologi dan Kejuruan edisi Mei 2003 oleh LPM-UNY)

Riduwan. 2012. Belajar Mudah Penelitian Untuk Guru, Karyawan, Peneliti Pemula. Bandung: Alfabeta.

Sampurno, Agus. 2006. Penerapan Metode Belajar Aktif dan Pembelajaran Berbasis Proyek. Jakarta: Rineka Cipta.

Siti Irene Astuti D. 2003. Pengembangan Kecakapan Hidup (life skill) Melalui Peranana Etos Kerja dan Membangun Kreativitas Anak. Yogyakarta: Cakrawala.

Sugiono, 2007. Statistika Untuk Penelitian. Bandung: Alfabeta.

Sugiono, 2010. Metode Penelitian Kuantitatif Kualitatif dan R\&D. Bandung: Alfabeta.

Sukidjo, 2003. Peranan Pendidikan Kecakapan Hidup (Life Skills) dalam Mengatasi Penganggguran Terdidik. Yogyakarta: Cakrawala Pendidikan.

Sumarmi, Sri. 2002. Konsep Dasar Pendidikan Kecakapan Hidup (life skill) dan Relefansinya dengan Pendidikan Islam, Jurnal IImu Pendidikan Islam, Vol.4 No. 3 hal 127)

Suryana, 2013. Ekonomi Kreatif, Ekonomi Baru: Mengubah Ide dan Menciptakan Peluang. Jakarta: Salemba Empat

Turgut, Hall. 2008. Prospective Science Teacher Conceptualizations About Project Based Learnin. International Journal of Instructions. Vol 1 No. 2. 61-79 (diakses melalui http://www.e-iji.net. 2608-2014)

Wahana, Paulus, 2004. Nilai Etika Aksiologis Max Scheler. Yogyakarta: Kanisius 